\title{
The Achievements of the GATT Uruguay Round
}

\section{Alan Oxley}

7 The 1993 agreements negotiated in the Uruguay Round constitute the most comprehensive overhaul of the multilateral trading system since the GATT

D was initiated in 1948. They strongly reinforce and extend the multilateral rules for trade; they alter the geo-politics that shape international trade; and they embody fresh commitments by the major economic powers to continue promoting global growth through expansion of global markets. But they will not diminish growing interest in regional arrangements.

\section{The GATT System}

The goal of the GATT is to convert all trade barriers to tariffs and progressively to reduce them. Thus, the GATT provides a mechanism to achieve free trade. When countries accede to the GATT, they agree to use only tariffs to regulate trade and to treat imports from all trading parties equally, and in a manner comparable to treatment of domestic products. They also agree to participate in successive 'rounds' of trade negotiations to reduce tariffs. The Uruguay Round is the eighth such round in 40 years.

The GATT has been successful. Industrialised countries adopted its rules and used its mechanisms to reduce trade barriers steadily throughout the $1950 \mathrm{~s}$ and 1960s. However, GATT has never been uniform in its effect, since countries have

\footnotetext{
In my experience, the best account of the basic commitments of the GATT which addresses both the legal and economic aspects of how GATT rules function is Hudec (1975), which is unfortunately rather dated. A more concise, contemporary and useful account of the international trade environment is found in Low (1993).
}

(c) 1994 Alan Oxley.

Alan Oxley is Managing Director of International Trade Strategies Pty Ltd, Melbourne, a former Australian Ambassador to the GATT, and former Chairman of the GATT Contracting Parties. He is the author of The Challenge of Free Trade (Harvester Wheatsheaf, 1990). 
been unwilling to liberalise certain areas of trade. They have ignored GATT rules, or created exemptions from them, or applied other rules.

\section{World Trade Before the Uruguay Round}

When the Uruguay Round began in 1986, a number of features of the organisation of world trade had come to be viewed as impediments to liberalisation.

- The level of protection, particularly in the United States, was rising.

- GATT rules were generally not applied in two key sectors of trade: agriculture, which constituted about 12 per cent of world trade, and clothing and textiles, which constituted about 7 per cent of world trade.

- Most developing countries did not apply the GATT rules on tariffs.

- Quotas and agreéments that disregarded GATT rules restrained trade in particular sectors, notably $\mathrm{EC}^{2}$ and US imports of steel and electronic consumer equipment.

- GATT restrictions on subsidies were weak.

- The US and the EC were using anti-dumping procedures to harass and restrict imports, particularly from Japan and other rapidly growing East Asian economies.

- GATT rules designed to obviate the negative impact of customs unions or freetrade areas on the trade of third parties were being ignored.

- The authority of the GATT dispute-settlement procedures had been weakened by the reluctance of the US and the EC to accept their jurisdiction in the agricultural sector.

Although tariffs had been reduced significantly in the 1960 s, the benefits to trade had been considerably eroded in the 1970s by increasing use of non-tariff barriers, especially in agriculture, clothing and textiles, steel, automobiles and consumer electronic goods. A number of codes to reduce the incidence of the impact of

${ }^{2}$ The European Community has three times changed its name: from European Economic Communities (EEC) to European Communities (EC) to European Union (EU). In this article, EC is used in references to events that occurred before the Maastricht Treaty came into effect in late 1993, when the abbreviation EU was adopted. 
non-tariff barriers were negotiated at the Tokyo Round (1976-79), but these had little impact.

The EC was unenthusiastic about a fresh round of trade negotiations. It had committed itself to its Single Market, which was intended to reduce barriers to trade inside the EC as well as to open up services markets. It was generally more interested in liberalising commerce within the EC than between the EC and the rest of the world; moreover, the EC's agricultural regime would be challenged in the GATT.

In retrospect, it is clear that developing countries in the 1980 s were willing to convert their unilateral reductions of trade barriers into multilateral commitments under the GATT. In the 1980s trade economists were largely preoccupied with the rise in global levels of protection. A number of studies indicate that in the late 1970s and early 1980s the effective rate of protection in the US rose. This led to claims that during the 1980 s global levels of protection rose markedly. Since trade with the US is such a significant component of world trade, a rise in protection in the US is likely to push up any measure of the level of world protection. By the same token, the significant cuts in protection undertaken by many developing countries were overlooked. These changes have not received the recognition they deserve.

The main impetus for the Uruguay Round stemmed from international concern about the US Congress's growing interest in raising trade barriers across the board in order to restrain imports, especially from Japan. The US Administration promoted a GATT round as a way of deflecting this pressure from Congress. At the same time it encouraged interest groups to support multilateral trade liberalisation. Two interests emenged: the US finance sector, which wanted multilateral rules to promote liberalisation of global services markets; and the US pharmaceutical, information technology and recording industries, which wanted to graft rules into the GATT to promote protection of intellectual property. These had not traditionally come under GATT's jurisdiction; indeed many countries, particularly developing ones, fiercely contested their inclusion in the trade round.

\section{The Uruguay Round Outcomes}

A large number of agreements were negotiated in the Uruguay Round. ${ }^{3}$ The principal agreements were to

- reduce tariffs globally by one-third over ten years;

\footnotetext{
3

${ }^{3}$ The most comprehensive account publicly available to date is a synopsis and summary of the drafts of the agreements prepared by the author for Baker and McKenzie, London, and published as part of the Single European Manket Reporter by Kluwer, The Hague. The Australian Department of Foreign Affairs and Trade is preparing a comprehensive account of the outcome. A CD Rom providing the full texts of the agreements and a commentary on them is being prepared by IMFORMIT, Royal Melbourne Institute of Technology.
} 
- reduce protection in agriculture through: conversion of all trade barriers to tariffs; reduction over six years of budgets for agriculture by 36 per cent; and reduction of budgets for export subsidies by 36 per cent and reduction of the volume of produce exported by 21 per cent;

- convert all barriers to trade in clothing and textiles to tariffs over 15 years;

- impose new restrictions on subsidies, involving the phasedown of more directly trade-distorting subsidies;

- increase the authority of the GATT dispute-settlement systems;

- give the GATT Secretariat authority to review the trade policies of members;

- establish new standards for intellectual property and provide for enforcement of those standards;

- establish multilateral trade rules for the liberalisation of trade in services;

- create a World Trade Organisation to administer the GATT and other trade agreements negotiated under GATT auspices (some of them, such as the agreements on services and intellectual property, have no formal relationship to the original GATT).

It is clear that the Uruguay Round process helped contain the threat by the US Congress to impose an across-the-board barrier against imports. But we will never know how important it was in comparison with other factors, such as the gradual decline in the value of the dollar, which reduced the US trade imbalance and eased political pressure to 'do something'.

\section{Cuts in Across-the-Board Protection}

The agreements secure a commitment by all parties to reduce tariffs across the board by an average of one-third over a ten-year period. As well, a number of ancillary non-tariff arrangements will be negotiated away in particular sectors. This will not mean much in industrialised countries, where (with the exception of Australia and New Zealand) the average level of tariffs is 5 per cent. But it will have a noticeable affect in developing countries, whose average tariff levels range from 20 to 50 per cent.

What about the non-tariff barriers? In two areas where these have been high - agriculture and clothing and textiles - there is a commitment to phase them out. In agriculture, all non-tariff barriers have to be converted almost immediately into tariffs. This will not result in immediate cuts in protection. It was clear that the US and the EC would replace their non-tariff measures with tariffs set so high that 
even after the general cut of tariffs by a third (which was to apply also to these newly established tariffs) the effective level of protection would not be lower than before. However, given the different effects on trade of tariffs and non-tariff measures, the conversion of all barriers to tariffs over time is likely to have a (limited) liberalising effect.

In the case of clothing and textiles, a different mechanism to achieve conversion to tariffs is to be used. Tariff quotas (which allow a specified quantity of a product to enter at a lower than normal tariff level) are to be used to effect the adjustment over a twelve-year period. This should also produce a steady liberalising effect.

The agreements also affect other non-tariff barriers, such as 'voluntary restraint arrangements' and 'orderly marketing arrangements', which the EC and the US in particular have used in electronic consumer, automobile and steel markets. A Safeguards Agreement revises GATT rules on imposition of protection in emergencies. The US and the EC agreed to phase out 'voluntary' arrangements to manage trade, although the EU sought a specific exemption for its quota system to restrict imports of automobiles from Japan. (These arrangements are almost never properly 'voluntary'. The euphemism was coined in the 1970s, when Japanese exporters were told they could 'voluntarily' restrain the level of exports to avoid the costs of defending anti-dumping cases in the US.) On the face of it, this is a significant agreement. Oddly, it has not been criticised by industries in the US and the EU that were protected by 'voluntary' and 'orderly' arrangements. In the American case, this may reflect official assurances that the Section 301 retaliatory mechanisms in the US Trade Act remain unaffected by Uruguay Round commitments. Perhaps criticism will surface when the agreements are scrutinised by Congress later in 1994 .

Separate negotiations to develop a Multilateral Steel Agreement, designed to phase out the network of steel import quotas, particularly those imposed by the US, were not completed by the end of the Uruguay Round and, at time of writing, there is no certainty that there will be a successful conclusion.

The most important across-the-board changes in the rules of the GATT (as opposed to changes within existing rules) are those affecting subsidies. The Subsidies Code has been renegotiated, and now contains tangible commitments to avoid using trade-distorting subsidies (though some exceptions are provided for). Under the old rules, only direct subsidies of exports were prohibited, and then only on non-agricultural products and only by those parties to the GATT that subscribed expressly to that commitment. However, these changes will not have visible effects in the short term.

The agriculture agreement sets lower quantitative levels of government support for agriculture. A principal target is to cut general levels of financial assistance by $\mathbf{3 6}$ per cent (some exceptions permit direct payments to farmers). However, the base period for measuring the cuts is one in which levels of support to farmers were historically high. At lot of work needs to be done to assess the impact of these changes. 
What does all this amount to? It is too soon to make an educated guess at the quantitative impact of the Uruguay Round agreements on global levels of protection. But it seems reasonable to conclude that, among industrialised countries, the outcome will consolidate the liberalising trend of the early and mid1980s. The agreements include several new policy instruments that will constrain over time the use of non-tariff measures by industrialised countries, thus improving greatly on the meagre results of the Tokyo Round. Among developing economies too the agreements will consolidate the trend to liberalisation, and in a number of instances accelerate it. The agreements represent tangible commitments to cease increasing support for agriculture and are likely to achieve distinct reductions over the six-year period. The big issue in this sector is the extent to which the changes introduce market forces as determinants of shares of trade.

\section{Has the Authority of the GATT been Enhanced?}

The authority of the GATT has indeed been enhanced, through several, discrete agreements.

The regulatory systems of two major sectors of trade - agriculture and clothing and textiles - are to be amended to bring them into conformity with the rules of the GATT. In a legal sense, this goes beyond merely agreeing to convert non-tariff measures in these sectors into tariffs.

In the case of agriculture, the US will surrender a formal authority that it secured in 1955 not to apply GATT rules to certain aspects of agricultural trade. Switzerland will have to give up rights to special treatment for agriculture that it won when it negotiated its right of access to the GATT. The agreements formally abrogate the Multifibre Agreement, which provided GATT cover for the use of quotas, otherwise prohibited under GATT rules, that restricted imports of clothing and textiles from developing countries.

For the first time in the history of the GATT, developing countries have embraced GATT rules on tariffs in toto. Before the Uruguay Round agreements, the GATT's rules on tariffs were primarily applied by industrialised countries. Critics of the GATT in developing countries traditionally dubbed it a 'rich country club'. Yet developing countries themselves often refused to bind their tariffs according to GATT rules. The Uruguay Round largely rectifies this shortcoming.

\footnotetext{
The GATT's rules are structured so that undertakings to cut tariffs become binding obligations to other contracting parties. When one party commits to another to reduce tarifs on a product to a particular level, the deal is sealed under GATT rules when it lists this new tariff level in a schedule to its terms of accession to the GATT. The act of listing is to 'bind' the tariff. Once bound, it cannot be reversed without the approval of all members of the GATT. In the unusual event that a party wishes to raise a bound tariff, the usual pattern is to negotiate with the parties with whom it originally negotiated the tariff, generally conceding some change in a tariff in another area to compensate for the loss of trade agreed to occur as a result of a lifting of the previously bound tariff. The system has the general effect of making tariff cuts irreversible. It should not be forgotten that because of the rule that imports from all countries
} 
In addition, the right that developing countries had previously enjoyed to impose trade barriers in order to protect their balances of payments has been significantly curtailed in a specific agreement on the terms of application of the relevant provision of the GATT (Article XVIII). This provision had been abused by many developing countries.

Another result of the Uruguay Round, which has surprised close observers of the GATT, has been the strengthening of the authority of the GATT disputesettlement procedures. To a very large degree, this system operated only if the parties to the dispute gave their consent. Virtually all small-country members of the GATT have respected these procedures. But the US and the EC, especially in disputes over agricultural subsidies, were able to undermine the procedures if they were unhappy with the results (though this inclination diminished considerably from the mid-1980s). The Uruguay Round agreements make important changes to the dispute-settlement procedures, and commit all parties to accept more readily their findings.

The agreements give the GATT secretariat a new executive function of reviewing the trade policies of GATT members. This was agreed at a mid-term review of the Uruguay Round negotiations in 1988 and the new system has been in operation for three years. Previously, the primary function of the GATT secretariat had been to service administration of fulfilment of and challenges to rights that parties to the GATT enjoyed under the agreement. The surveillance function is an important extension of the functions of the GATT.

The conversion of the GATT into the World Trade Organisation is a significant constitutional change that will bring under the umbrella of the one organisation the operations of the two most important new treaties, the General Agreement on Trade in Services (GATS) and the Agreement on Trade Related aspects of Intellectual Property. A common secretariat will service these agreements and a common system of dispute settlement will be used to deal with challenges under them.

\section{Broadening the Scope of the GATT}

The agreements on services and intellectual property represent the most radical alteration of the jurisdiction and mandate of the GATT, which was originally intended to apply only to trade in goods. The GATS applies to all sectors other than those formally excluded. Financial services and telecommunications are the two most heavily traded service sectors and therefore represent touchstones of the effectiveness of the agreement. Further negotiations are to be held in both sectors.

Extending the GATT to services is a visionary move that recognises that continuing promotion of the efficiency of global markets requires globalisation of

must be treated equally, a commitment to one country to bind a tariff provides a level of access and benefit to all other parties to the GATT. 
services markets, which are acquiring a greater share of world trade. Greater efficiency in global services markets is also becoming an increasingly important factor in global competitiveness in international trade in goods. The effort to remove remaining barriers to trade in goods among industrialised economies may have reached the point of diminishing returns compared to the greater benefit potentially available from liberalisation of international trade in services. Work on this will have to await a greater familiarity with the issues among trade economists.

The intellectual-property agreement extends the GATT's dispute-settlement provisions to intellectual-property standards. Any country will be able to use the GATT dispute-settlement mechanism in challenging non-application of intellectualproperty rights in another country. Securing this change was a major source of US support for the Uruguay Round agreements.

The GATT has thus been substantially refurbished. But two areas of weakness remain untouched. The rules designed to ensure that regional trade agreements (free-trade areas and customs unions) do not undermine the general benefits that GATT parties are entitled to expect from their trading partners are not substantially changed. GATT requires that regional agreements must not increase trade restrictions between members of the regional arrangement on the one hand and other parties to the GATT on the other. Application of the relevant GATT test for this outcome has waned over the years, and regional agreements are nowadays reviewed in a rather perfunctory manner.

Nor do the Uruguay Round agreements properly address anti-dumping. The anti-dumping code has been revised, but not significantly. GATT rules give individual members considerable discretion over the working of anti-dumping systems, thus leaving intact an emerging protectionist measure.

\section{The Geo-political Significance of the Uruguay Round}

The Uruguay Round began in 1986 and was supposed to finish in 1990. It formally concluded in 1994. While the negotiations dragged on several important changes to the structure and institutions of international trade occurred. The most important were in Europe and North America.

The EC negotiated and implemented the Single Market. The European Economic Area was also established to enable the countries of the European Free Trade Area (except Switzerland) to participate in the Single Market. The US negotiated a free-trade agreement with Canada and then extended it to Mexico in the NAFTA. Other moves towards regional trade liberalisation included the ASEAN countries' commitment to a free-trade area, and the move by Brazil, Argentina, Uruguay and Paraguay to establish a free-trade area customs area, the MERCOSUR arrangement. Discussions about economic integration also took place among countries in the Pacific Rim. APEC was launched and the Malaysians promoted the idea of an East Asian Economic Caucus.

The collapse of the Soviet Union while the Round was in progress discredited the command-economy model and focused attention even more on the export- 
oriented East Asian development model. Two effects were to increase the number of countries seeking membership of the GATT and to promote the importance of trade in international relations. In international debate on trade, the issue was whether the multilateral trade system promoted by the GATT was being supplanted by regional trade arrangements. The conclusion of the Uruguay Round has shown that the GATT was not supplanted. The patterns of trade showed that its rules were robust. Analyses by the GATT secretariat showed that trade between regions was growing faster than trade within regions, mainly because of the rapid growth of the East Asian economies.

But the GATT was in some danger of being pushed to one side. The EU and the North American countries had promoted regional trade agreements. The impetus for these changes was as much political as economic, especially in Europe after the collapse of the USSR. The risk for the GATT was that the US and the EU had given a higher priority to these regional arrangements than to the GATT.

But the Uruguay Round outcomes represent a renewed commitment by the major economic powers to promote growth by creating and expanding global markets. Nevertheless, the pressures towards regional agreements will not disappear. The $\mathrm{EU}$ has a long-term commitment to further expansion and integration. Other countries will seek free-trade agreements with the US. But the successful conclusion of the Uruguay Round allows us to view these regional tendencies with less concern.

\section{Conclusion}

The long-term influence of the Uruguay Round agreements on the direction of international economic management may be as significant as the influence of the GATT itself when it was negotiated in 1948. The scope of economic activity that is to be subject to multilateral rules has been extended, warranting reconstruction of the GATT into a World Trade Organisation. Acceptance of the basic precepts of the GATT has spread from industrialised countries to most developing countries. At a time when interest in regional trade arrangements has been strong, the authority of the GATT system of multilateral rules has been renewed.

\section{References}

Hudec, C. (1975), The GATT Legal System and World Trade Diplomacy, Praeger, New York.

Low, P. (1993), Trading Free: The GATT and US Trade Policy, Twentieth Century Fund Press, New York. 